\title{
Nervous system and neurosecretory cells in cestoda Lytocestus vyasaei Pawar, 2011 (Caryophyllidea)
}

\author{
Rajkumar T. Pawar \\ Department of Zoology, Sunderrao Solanke Mahavidyalaya, Majalgaon Dist. Beed, Maharashtra, India. \\ Correspondence Author: drrajtpawar@gmail.com
}

Available online at: www.isroset.org

Received: 29/Jan/2019, Accepted: 14/Feb/2019, Online: 28/Feb/2019

\begin{abstract}
The nervous system and neurosecretory cells of cestode Lytocestus vyasaei (Caryophyllidae) was investigated using histochemistry on the basis cytological structure. Morphologically the central nervous system consists of cephalic ganglionic mass and the lateral longitudinal nerve cords. The cephalic ganglionic mass consists of moderate number of apolar cells, unipolar cells, bipolar cells, and few multipolar cells, which are darkly stained. The bipolar cells are spindle shaped with two axons, unipolar cells are rounded with single axon and multipolar cells are with many axons with full neurosecretory material. The present findings suggest that and neurosecretory cells in nervous system may play an important integrative role of both neuronal and endocrine in the flatworm.
\end{abstract}

Keywords: Lytocestus vyasaei (Cestoda), Nervous system, neurosecretory cells, Clarias batrachus etc.

\section{INTRODUCTION}

The nervous system of platyhelminthes is significant, because it represents an intermediate stage in the evolution of the nervous system. It has been assumed that, the adoption of a parasitic mode of life by groups, such as cestodes, must necessarily have led to a reduction or secondary simplification of their nervous system, or that the sedentary life style of the adult does not require a very elaborate or well-organized nervous system. It is assumptions that have been responsible in part, for the lack of interest shown in the nervous system of the cestodes.

Many scientists have worked out the nervous system of cestode parasites, [1] illustrated that there are 10 longitudinal nerve cords, interconnected by 20 transverse strands. The ten nerve cords anteriorly branched from a nerve ring in the neck and join in the centre of the scolex at a second ring. This was described in C. mutabilis and was considered to be most like that of trematodes. Later this theory was criticized by Luhe [2] that it did not differ from other cestodes in having 10 longitudinal cords. Another theory was proposed by Mrazk [3] that a single large scolex bears a nerve ring, a dorsal and a ventral nerve cord and two lateral cords with 16 nodes. Johnstone [4] described the nervous system of trypanorhynchan tapeworm Grillotia orienaceus. Shield [5] described the nervous system of Dipylidium ganinum, E. granulosus and Hydatigera taeniaeformis and confirmed to the typical cyclophyllidean pattern.
Present knowledge of the nervous system of cestodes shows that there are at least two longitudinal nerve cords this theory is well established. Regarding the neurosecretory system it is indicating that there are two classes of neurosecretory cell bodies, one type being neurosecretory, the other non-neurosecretory. The cytology of the nervous system consists various ganglionic cells and was identified at cerebral ganglia. But Rees [6] observed in Acanthobothrium coronatum that, the commissures constitute the nervous system. There is an opinion that the nervous system arises from the neurosecretory cells, this was observed by Andrew et al. [7]. Pintner [8] described giant fibers, originating from large multipolar cells, in the posterior commissure and running along with the nerve fibers, of the lateral cords and the tentacular nerves.

The purpose of the present study is a reexamination of the earlier studies and re-description of functional ultrastructure of the caryophyllaidea cestode Lytocestus vyasaei nervous system and neurosecretory cells. In the present investigation an attempt has been made to study the nervous system and neurosecretory cells of the cestode worms Lytocestus vyasaei [9] collected from the freshwater fish, Clarias batrachus (L) Marathwada region of Maharashtra state, India.

\section{MATERIAL AND METHODS}

Eleven freshwater air breathing fish Clarias batrachus (Linnaeus) were brought to the laboratory from 
the Kham River at Aurangabad district and dissected out and the intestine were examined for cestode infection. Out of eleven intestines, four intestines were heavily infected. The identified worms were separated and few of them were fixed in $4 \%$ formalin for taxonomical studies and rest was fixed in Bouin's fluid at 24-48 hours.

The material was washed in distilled water and Lithium carbonate solution, then dehydrated in alcohol grades and embedded in paraffin wax. $\left(58-60^{\circ} \mathrm{C}\right)$. Blocks were cut at $7 \mathrm{~m} \mu$ and slides were stained with Mallory's triple stain [10]. The best slides were selected after observation and the visual criteria of specific histochemical staining were adopted for determining the nervous system and neurosecretory cells.

\section{RESULT AND DISCUSSION}

The nervous system of the cestode Lytocestus vyasaei has the central nervous system which is clearly visible. The central nervous system consists of cephalic ganglionic mass and the lateral longitudinal nerve cords. From the cephalic ganglionic mass, two longitudinal nerve cords are running anterior head region to posterior region; these cords are thick and contain bundles of nerve fibers and neurosecretory cells. The neurosecretory cells are found in corticular parenchamatous tissue in head and neck region (Fig. A \& B).

The cephalic ganglionic mass consists of moderate number of apolar cells, unipolar cells bipolar cells, and few multipolar cells, which are darkly stained. The bipolar cells are spindle shaped with two axons, unipolar cells are rounded with single axon and multipolar cells are with many axons with full neurosecretory material. The Longitudinal section of middle and posterior region of the worm, four types of neurosecretory cells are located in the longitudinal nerve cord and peripheral region also more number of cells occurs in longitudinal muscle and reproductive components (Fig. C \& D).

Morphologically, apolar cells are round or oblong in shape, with or without axons and nucleus is round, red in color, the cytoplasm shows affinity with Mallory's triple stain that is pinkish violet in color. The unipolar cells are medium in size and spherical in shape, with single axon and nucleus is round or dark stained and the cytoplasm stained pinkish violet in color. The bipolar cells are larger than unipolar cells and spindle in shape, with two axons and cytoplasm gave weak staining with Mallory's triple stain. The multipolar cells are many in number it is found in cephalic ganglionic mass of the middle region of worm and the cytoplasm gave weak staining with Mallory's triple stain (Fig. E \& F).

In Lytocestus indicus, Putative neurosecretory cells (pNSC) are recognized on the basis of phloxinophilic and Fuchsinophilic nature of their cytoplasm, pNSC in L. indicus are dimensionally small. Morphologically, there are four types of pNSC i.e. apolar, unipolar, bipolar and multipolar cells are found both in the cortical and medullary parenchyma of the neck and strobilar regions also he observed in longitudinal muscles and components of the reproductive system. In the present study four types of neurosecretory cells are found in cephalic ganglionic mass of middle region of worm, these are apolar, unipolar, bipolar and multipolar cells and results are in accordance with Lyngodh et.al. [11]. Similar observation was done by Shinde, G.B. et.al. [12] in the nervous system of Raillitina (Raillietina) tetragona consist of an anterior nerve ring in rostellum with a number of nerve cells in a ring formed by a number of bipolar cells, with few unipolar and multipolar cells, which are larger, their nuclear membrane thin and smooth, nucleolus large and darkly stained.

\section{CONCLUSION}

The nervous system in cestode parasites has proved exceedingly difficult to study, due to the lack of a delimiting sheath on the nerve trunks, and to the subsequent problems of demonstrating the nerves by routine staining methods. In this study caryophyllidea cestodes observed that cephalic gangelionic mass with neurosecretory cells and lateral longitudinal nerve cords which are darkly stained.

\section{Acknowledgement:}

The authors are thankful to Prof. and Head Department of Zoology, Dr. Babasaheb Ambedkar Marathwada University, Aurangabad for providing the research laboratory facility.

\section{REFERENCES}

[1]. Will, H. (1893): Anatomie von Caryophyllaeus mutabilis Rud. Ein Beitrag zur Kenntnis der Cestoden. Zeitschrift für Wissenschaftliche Zoologie 56: 1-39

[2]. Luhe (1902): Z, Wiss, Zool. 68: 97-99.

[3]. Mrazek, A. (1898): Archigetes appendiculatus Ratz. In Věstnik Kral. Česke Společnosti Nauk, Třida mathematicko-přirodovědecka 32. Královská Česká Společnost Nauk, Prague, Czech Republic, p. 47.

[4]. Johnstone, J.H. (1912): Nerve cells in the ganglia of Crillotia erinaceus. Proc. New South Wales 36: 58-80.

[5]. Shield, J. M. (1969): Dipylidium caninum, Echinococcus granulosus and Hydatigera taeniformis. Histochemical identification of Cholinesterase. Expl. Parasit., 25: 217-231.

[6]. Rees G. (1966): nerve cells in Acanthrobothrium coronatum (Rud.) (Cestoda: Terraphyllidae). Parasitology 56, 45-54

[7]. Andrews P, (1983): Thomas H, Pohlke R, Seubert J. Praziquantel. Med Res Rev. ;3:147-200.

[8]. Pintner T. (1934): Bruchstuecke zur Kenntnis der Ruesselbandwuermer. Zool. Jahrb., Abt. Anat. Ontog. Tiere 58:120

[9]. R. T. Pawar and C.J. Hiware (2011): Two New Species of the Genus Lytocestus (Caryophyllidea- Lytocestidae) from Freshwater Catfish, Clarias Batrachus Linnaeus (1758)". Recent Research in Science and Technology, Vol. 3, no. $12,25-28$

[10]. Mallory FB. The aniline blue collagen stain Stain Technol 1936; 11:101-102. 
[11]. Lyngodh, Radiancy D., and Tandon Veena (1998): Putative neurosecretory cells in the monozoic cestode, Lytocestus indicus (caryophyllidea). Acta Parasitologica, Vol.43 No.4, 217-221.
[12]. Shinde, G.B. and Mitra, K.B. (1979): Studies on the nervous system of $R$. (R.) tetragona (Molin, 1858). Biores, 3 (20): 31-39.
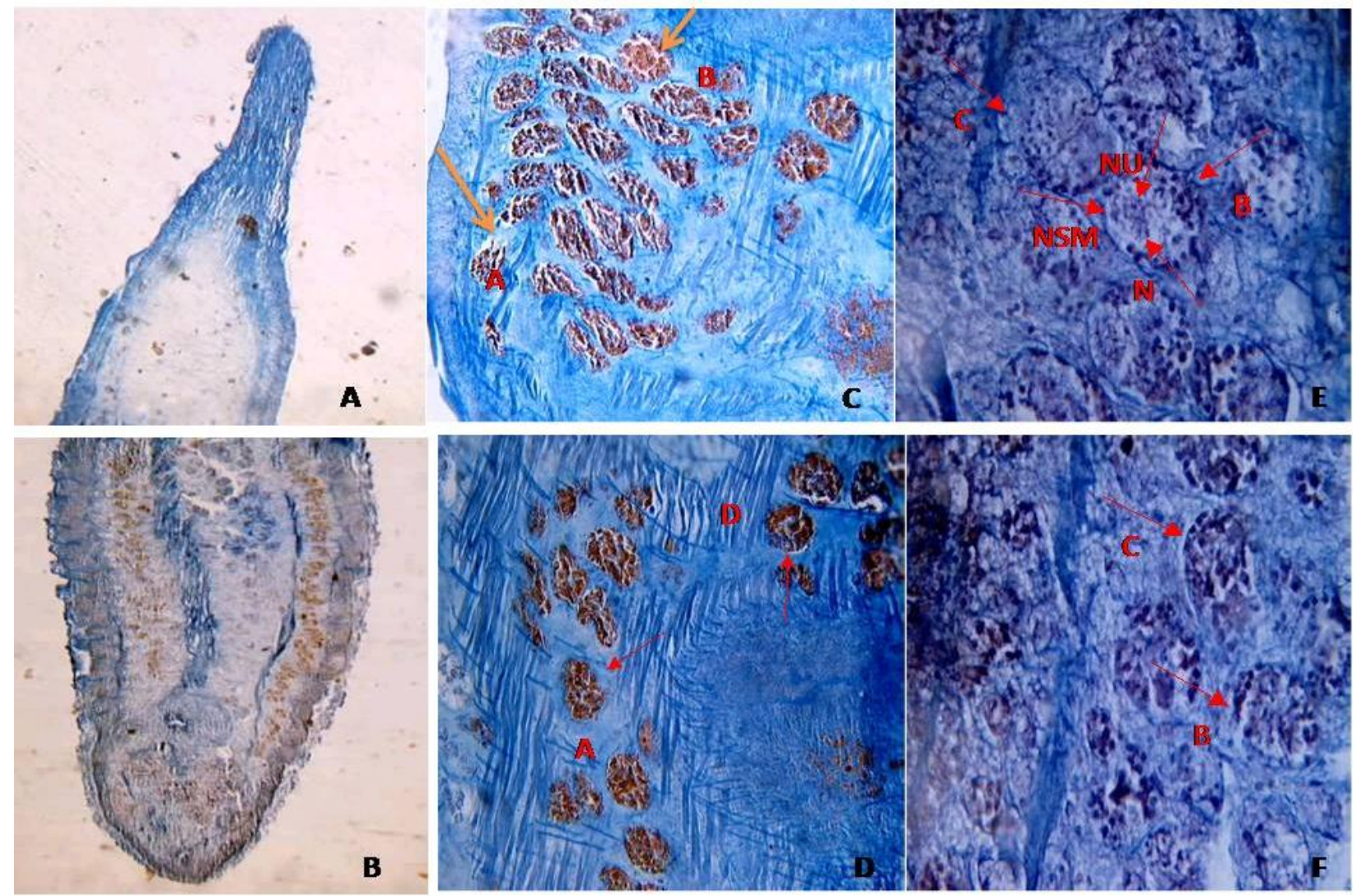

\section{Nervous system and neurosecretory cells in Lytocestus vyasaei}

Fig.A. L.S. of head region showing central nervous system and neurosecretory cells in corticular paranchymatous tissue.

Fig.B. L.S. of middle and posterior region showing longitudinal nerve cord and neurosecretory cell.

Fig.C. L.S. of middle region of worm showing - A and D types of nreurosecretory cells. A- Apolar D- Multipolar

Fig.D. L.S. of middle region of worm showing A and D types of nreurosecretory cells- A- Apolar D- Multipolar

Fig.E. L.S. of middle region of worm showing - B and C types of nreurosecretory cells-B- Unipolar, C- Bipolar, N- Nucleus, NU- Nucleolus, NSM- Neurosecretory material

Fig.F. L.S. of middle region of worm showing - B and C types of nreurosecretory cells- B- Unipolar, C- Bipolar 